Jurnal Farmamedika Vol.5 No.1 Juni 2020

\title{
GAMBARAN HISTOPATOLOGI OTAK MENCIT (Mus musculus L) SETELAH PEMBERIAN FRAKSI DAUN SEMBUNG RAMBAT (Mikania micrantha Kunth) SEBAGAI AKTIVITAS NEUROPROTEKTAN
}

\author{
Agdes Amelia ${ }^{1 *}$, Yuni Andriani ${ }^{2}$, Lili Andriani ${ }^{3}$ \\ 1.2.3Program Studi S1 Farmasi, Sekolah Tinggi Ilmu Kesehatan Harapan Ibu, Jambi, Indonesia \\ Korespondensi : agdesameliaaa@gmail.com
}

\begin{abstract}
ABSTRAK
Sembung rambat (Mikania micrantha Kunth.) diduga memiliki aktivitas neuroprotektan terhadap penyakit demensia, tanaman ini memiliki metabolit sekunder flavonoid. Penelitian ini bertujuan untuk mengetahui apakah fraksi daun sembung rambat memiliki aktivitas neuroprotektan berdasarkan gambaran histopatologi otak mencit. Metode yang digunakan yaitu ekstraksi lalu dilanjutkan dengan fraksinasi menggunakan metode ekstrak cair-cair dengan pelarut $n$-heksan, etil asetat dan $n$-butanol kemudian diuji dengan menggunakan 25 ekor mencit jantan yang terdiri atas 5 perlakuan. Pada perlakuan ini terdiri dari kontrol negatif (diazepam), kontrol positif (piracetam), dan perlakuan fraksi T1, T2 \& T3 dengan dosis $500 \mathrm{mg} / \mathrm{kgBB}$ dalam waktu pemberian selama 14 hari. Pengamatan histologi otak dilakukan dengan cara mengeutinasi dihari ke-15 setelah pemberian masing-masing perlakuan. Potongan otak bagian hipokampus diamati dengan pewarnaan Hematoksilin dan Eosin (HE). Hasil pengamatan histopatologi otak terhadap sel neuron pada kelompok uji kontrol negatif (diazepam), fraksi etil asetat (T2), dan fraksi n-heksan (T1) menunjukkan banyaknya nekrosis sel (kematian sel) neuron. Sementara pada kelompok uji fraksi n-butanol (T3) dan piracetam menunjukkan sedikitnya nekrosis sel (kematian sel) neuron. Nekrosis sel (kematian sel) ditandai dengan sel neuron otak dengan inti yang mengkerut dan sitoplasma berwarna lebih eosinofilik. Berdasarkan hasil penelitian yang telah dilakukan dapat disimpulkan bahwa Fraksi daun sembung rambat memiliki aktivitas sebagai neuroprotektan.
\end{abstract}

Kata kunci: Daun Sembung rambat (Mikania micrantha Kunth.), Histopatologi, Neuroprotektan

\begin{abstract}
Sembung rambat (Mikania micrantha Kunth.) Is thought to have neuroprotectant activity against dementia, this plant has secondary metabolites of flavonoids. This study aims to determine whether the leaf fraction of sembung rambat has neuroprotectant activity based on the histopathology of the brain of mice. The method used was extraction followed by fractionation using the liquid-liquid extract method with n-hexane, ethyl acetate and n-butanol solvents and then tested using 25 male mice consisting of 5 treatments. In this treatment consisted of negative control (diazepam), positive control (piracetam), and treatment of the T1, T2 \& T3 fractions with a dose of $500 \mathrm{mg} / \mathrm{kgBW}$ within 14 days of administration. Brain histology observations were carried out by eutinating on the 15th day after giving each treatment. Hippocampal brain sections were observed with Haematoxylin and Eosin (HE) staining. The results of brain histopathology observations on neuron cells in the negative control group (diazepam), ethyl acetate fraction (T2), and n-hexane fraction (T1) showed the number of cell necrosis (cell death) of neurons. Meanwhile, the n-butanol (T3) and piracetam fraction groups showed the least cell necrosis (cell death) of neurons. Cell necrosis (cell death) is characterized by brain neuron cells with a constricted nucleus and a more eosinophilic colored cytoplasm. Based on the results of research that has been done, it can be concluded that the fraction of sembung rambat has activity as a neuroprotectant.
\end{abstract}

Keywords: Leaves of Sembung rambat (Mikania micrantha Kunth.) $1^{\text {st }}$, Histopathology $2^{\text {nd }}$, Neuroprotectant $3^{\text {rd }}$ 


\section{PENDAHULUAN}

Tanaman sembung rambat (Mikania micrantha Kunth) diketahui mengandung senyawa metabolit sekunder seperti alkaloid, flavonoid, saponin, dan tannin. Dimana tanaman ini telah banyak digunakan sebagai obat tradisional, seperti mengobati gigitan serangga atau sengatan kalajengking, untuk mengobati penyakit kulit, diabetes, stroke, hiperkolesterolemia, dan hipertensi ${ }^{5}$. Tanaman ini juga memiliki khasiat diantaranya sebagai antitumor, sitotoksik, analgesik, anti inflamasi, antiproliferatif, pitotoksik ${ }^{8}$, aktivitas anti stress dan koagulan ${ }^{11}$.

Telah dilakukan penelitian tanaman sembung rambat tentang, studi in vivo aktivitas ekstrak dan fraksi tanaman sembung rambat yang digunakan untuk meningkatkan performa memori pada hewan mencit putih model demensia, pada hasil uji ditemukan peningkatan yang signifikan dimasing-masing kelompok uji $^{3}$.

Demensia merupakan suatu sindrom yang dimana sel-sel saraf otak tidak berfungsi dengan normal atau bahkan mengalami kematian. Kematian atau kerusakan sel-sel saraf menyebabkan perubahan dalam memori seseorang, perilaku, dan kemampuan untuk berpikir jernih ${ }^{14}$.

Tanaman sembung rambat memiliki potensi neuroprotektan terhadap hewan mencit putih model demensia, sehingga peneliti tertarik untuk melakukan penelitian lanjutan mengenai gambaran histopatologi otak mencit setelah pemberian fraksi daun sembung rambat sebagai aktivitas neuroprotektan.

Penelitian ini bertujuan untuk mengetahui apakah fraksi daun sembung rambat memiliki aktivitas neuroprotektan berdasarkan gambaran histopatologi otak mencit.

\section{METODE PENELITIAN}

Bahan : daun sembung rambat, aquadest, etanol 70\% (Merck), Na CMC, n-heksan (Merck), etil asetat (Merck), n-butanol (Merck), alkohol $70 \%$ (Merck), larutan $\mathrm{NaCl}$ fisiologis, silol, pewarnaan hematoksiklin eosin, larutan bouins, larutan fiksatif $\mathrm{NaCl}$, diazepam, piracetam, mencit, pakan mencit.

Alat : erlemeyer, gelas ukur, tabung reaksi, rak tabung, beker gelas, corong pisah, cawan penguap, alat bedah, corong, vial, spatel, batang pengaduk, plat tetes, kertas saring, neraca analitik (Mettler Toledo AL204®), wadah pemeliharaan, timbangan hewan, alat suntik, jarum oral, rotary evaporator (KIA), object glass, cover glass, penjepit, pot kecil tempat penyimpanan organ.

\section{Metode \\ Metode yang digunakan adalah metoda eksperimental in vivo dengan menggunakan mencit putih jantan (Mus musculus L) sebagai hewan uji.}

\section{Pengambilan dan Penyiapan Sampel}

Sampel uji yang digunakan adalah daun sembung yang didapat di Sungai Gelam, Muaro Jambi sebanyak $2 \mathrm{~kg}$ dalam keadaan sampel basah.

\section{Ekstraksi}

Daun sembung rambat segar sebanyak $2 \mathrm{~kg}$ dicuci dengan air dan dikeringanginkan sampai berat konstan. Sampel yang sudah kering dirajang, kemudian di rendam menggunakan pelarut etanol $70 \%$. Proses maserasi dilakukan hingga diperoleh larutan bening. Larutan yang didapat dicampurkan, kemudian dipekatkan dengan menggunakan vacuum rotary evaporator pada suhu $50^{\circ} \mathrm{C}$ sampai diperoleh ekstrak kental ${ }^{12}$.

\section{Fraksinasi}

Ekstrak daun sembung rambat difraksinasi dengan cara ekstraksi cair-cair (ECC) menggunakan pelarut dengan berdasarkan tingkat kepolarannya. Sampel dimasukkan dalam corong pisah. Proses fraksinasi diawali dengan pelarut n-heksan (non polar) secukupnya dan dilakukan beberapa kali pengulangan sampai pelarut bening, sehingga akan didapat 2 fase yaitu fase $n$-heksan dan fase air. Fraksi n-heksan pelarutnya diuapkan di in vacuo sehingga didapat fraksi kental n-heksan. Fase air dilanjutkan dengan pelarut etil asetat (semi polar) secukupnya, dilakukan beberapa kali pengulangan, sehingga didapat 2 fase yaitu fase etil asetat dan fase air. Fase etil asetat pelarutnya diuapkan di in vacuo sehingga didapat fraksi kental etil asetat. Fase air dilanjutkan dengan pelarut n-butanol (polar), kemudian semua fraksi tersebut pelarutnya diuapkan di in vacuo sehingga didapat fraksi kental.

\section{Penapisan Fitokimia}

Ekstrak dan fraksi yang diperoleh kemudian diuji fitokimia berupa uji kualitatif golongan senyawa alkaloid, flavonoid, saponin, tanin, 
steroid, dan terpenoid ${ }^{11}$.

Persiapan Hewan Uji dan Perencanaan Dosis

Hewan percobaan yang digunakan yaitu mencit putih dengan galur yang berusia 2-3 bulan, dengan berat 20-25 g sebanyak 25 ekor dan belum pernah mengalami perlakuan terhadap obat. Dosis yang digunakan untuk masingmasing fraksi adalah $500 \mathrm{mg} / \mathrm{kgBB}$, piracetam $800 \mathrm{mg} / \mathrm{kgBB}$ dan diazepam $0,75 \mathrm{mg}$.

Untuk membuat model hewan uji demensia, diberikan Diazepam injeksi dengan dosis 0,75 mg selama lima hari. Diazepam digunakan sebagai penginduksi merusak otak sehingga memperlambat performa memori hewan uji. Kemudian setiap kelompok diberikan masing masing fraksi dengan dosis $500 \mathrm{mg} / \mathrm{kg}$ BB. Pemberian dilakukan secara oral dengan alat sonde dan volume pemberian $0,2 \mathrm{ml} / 20 \mathrm{~g} \mathrm{BB}$. Kelompok kontrol (-) hanya berikan diazepam injeksi i.p dan sebagai kontrol (+) diberikan Piracetam. Fraksi daun sembung rambat, dan piracetam diberikan selama empat belas hari berturut-turut.

\section{Pengambilan Jaringan Otak}

Pada hari ke 15 mencit dikorbankan, mencit didislokasi pada bagian leher, kemudian dilakukan pembedahan pada bagian kepala dan organ otak diangkat. Otak yang telah diisolasi direndam kedalam garam $\mathrm{NaCl}$ fisiologis sampai bersih. Setelah itu, otak dimasukkan kedalam larutan bouins dan larutan fiksatif $\mathrm{NaCl}$. Organ otak dibuat blok parafin. Kemudian blok diiris dengan ketebalan 3-5 $\mu \mathrm{m}$ dengan menggunakan mikrotom sehingga diperoleh bagian hipokampus untuk analisis histopatologi dengan pewarnaan Hematoksilin dan $\operatorname{Eosin}^{7}$.

\section{Pewarnaan Hematoxilin dan Eosin}

Pewarnaan preparat histologi diawali dengan proses deparafinisasi kedalam larutan silol sebanyak $2 x$ celupan selama 30 menit. Proses rehidrasi untuk menghilangkan silol dengan memasukkan preparat ke dalam larutan alkohol absolut selama 2 menit, kemudian dimasukkan lagi kedalam larutan alkohol 95\% hingga 70\% selama 1 menit. Selesai rehidrasi, dilanjutkan pencucian preparat dengan air mengalir. Selanjutnya pewarnaan hematoksilin selama 8 menit. Tahap selanjutnya adalah pencucian lagi dengan air mengalir selama 2 menit. Proses pewarnaan eosin selama 2 menit, kemudian preparat dicuci dengan air mengalie. Setelah pewarnaan eosin selesai, preparat histologi didehidrasi kedalam larutan alkohol 95\% dan alkohol absolut sebanyak 2 kali selama 2 menit. Lalu perendaman preparat menggunakan silol sebanyak 2 kali selama 2 menit, kemudian preparat ditutup dengan kaca penutup menggunakan bahan perekat permount, dan diberi label ${ }^{15}$.

\section{Pemeriksaan Histopatologi}

Uji histopatologi dilakukan di Laboratorium Patologi, Fakultas Kedokteran Hewan, Institut Pertanian Bogor (IPB) Bogor, Jawa Barat. Uji ini untuk melihat di penunjang pada otak saat terjadi kerusakan.

\section{Analisa Data}

Gambaran histopatologi otak mencit dianalisa secara deskriptif dengan melihat nekrosis $\mathrm{sel}^{7}$.

\section{HASIL DAN PEMBAHASAN}

Jenis penelitian ini bersifat preventif, dimana preventif merupakan pengujian yang bersifat mencegah terjadinya suatu penyakit. Pada penelitian ini digunakan fraksi daun sembung rambat (Mikania micrantha Kunth) yang diperoleh di Sungai Gelam, Muaro Jambi. Berdasarkan hasil determinasi, tumbuhan sembung rambat yang digunakan sesuai dengan klasifikasi pada umumnya.

Proses ekstraksi tanaman dari daun segar sembung rambat sebanyak $2000 \mathrm{~g}$ dan didapat simplisia kering dengan berat $214 \mathrm{~g}$, yang menghasilkan berat ekstraksi sebanyak 65,29 g dengan rendemen $30,50 \%$. Semakin besar nilai rendemen suatu ekstrak yang diperoleh menandakan nilai ekstrak yang dihasilkan semakin banyak. Proses fraksinasi sebanyak 60,29 g ekstrak. Tujuan dilakukannya fraksinasi adalah untuk memisahkan senyawa berdasarkan tingkat kepolarannya. Hasil fraksinasi yang didapat untuk fraksi n-heksan sebanyak 6,46 g dengan rendemen $10,7 \%$, untuk fraksi etil asetat sebanyak $10,72 \mathrm{~g}$ dengan rendemen $17,7 \%$ dan fraksi n-butanol sebanyak 13,01 $\mathrm{g}$ dengan rendemen $21,5 \%$.

Hasil pengujian skrining fitokimia daun sembung rambat ditemukan beberapa senyawa diantaranya alkaloid, flavonoid, tannin, saponin, dan steroid. Hal ini sejalan dengan beberapa penelitian yang mengatakan ekstrak dan fraksi daun sembung rambat mengandung alkaloid, steroid, terpenoid, flavonoid, tanin, dan $\operatorname{tanin}^{3,11}$. Berdasarkan hasil uji skrining fitokimia pada penelitian ini bahwa flavonoid 
positif terdapat pada ekstrak dan fraksi nbutanol dan negatif pada fraksi etil asetat dan nheksan. Pada pengujian alkaloid hasil positif terdapat pada ekstrak dan semua fraksi.

Pada pengujian tanin positif terdapat pada ekstrak dan fraksi n-butanol. Tanin pada uji ini termasuk pada golongan tanin kondensasi yang mana pada uji tannin ini menghasilkan warna hijau kehitaman pada saat penambahan $\mathrm{FeCl}_{3}$ karena bereaksi dengan salah satu gugus hidroksil yang ada. Pada senyawa tanin hasil reaksi menimbulkan warna, juga dapat mengidentifikasi senyawa fenol diduga hasil positif dapat di sebabkan oleh adanya fenolik lain dalam sampel ${ }^{2}$. Pada pengujian saponin positif terdapat pada ekstrak dan fraksi n- heksan namun negatif pada fraksi etil asetat dan fraksi n-butanol. Saponin bersifat polar sehingga dapat larut dalam pelarut seperti air dan saponin juga bersifat non polar karena memiliki gugus hidrofob yaitu aglikon (sapogenin). Busa yang dihasilkan pada uji saponin disebabkan karena adanya glikosida yang dapat membentuk busa dalam air dan terhidrolisis menjadi glukosa dan senyawa lainnya ${ }^{1}$. Pada pengujian steroid hasil positif terdapat pada ekstrak dan fraksi n-heksan, Pada hasil skrining fitokimia penelitian ini ada beberapa senyawa yang seharusnya positif namun menunjukkan hasil negatif, hal ini terjadi karena pada saat pemisahan senyawa aktif tidak terjadi dengan sempurna.

Tabel 1. Kandungan Fitokimia Ekstrak dan Fraksi daun sembung rambat

$\begin{array}{lllll}\text { Pengujian } & \text { Ekstrak } & \text { T1 } & \text { T2 } & \text { T3 }\end{array}$

Alkaloid

\begin{tabular}{|c|c|c|c|c|c|}
\hline & Pereaksi Mayer & + & + & + & + \\
\hline & Pereaksi Dragendorf & + & + & + & + \\
\hline Saponin & & + & + & - & - \\
\hline Tanin & & + & - & - & + \\
\hline Flavonoid & & + & - & - & + \\
\hline Steroid & & + & + & - & - \\
\hline
\end{tabular}

Keterangan : T1 (Fraksi n-heksan), T2 (Fraksi etil asetat), dan T3 (Fraksi n-butanol)

(+) : Positif, (-) : Negatif

\section{Uji Histologi}

Pada uji histologi, preparat dibuat sesuai standar operasional prosedur dengan pewarnaan hematoksilin-eosin, pewarnaan hematoksilineosin mewarnai merah muda untuk sitoplasma dan biru tua untuk inti. Pada penelitian ini pengamatan dilakukan pada bagian hipokampus otak. Hipokampus diketahui memiliki peran penting dalam fungsi kognitif, mengontrol umpan balik pada respon stress, dan proses belajar dan mengingat. Hasil pembacaan sel pada area hipokampus bagian dentate gyrus dengan perbesaran 400x pada setiap kelompok dapat dilihat pada gambar berikut : 


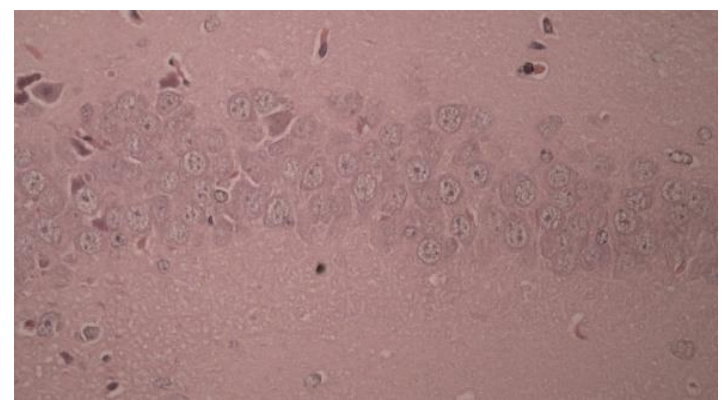

Gambar 1. Normal

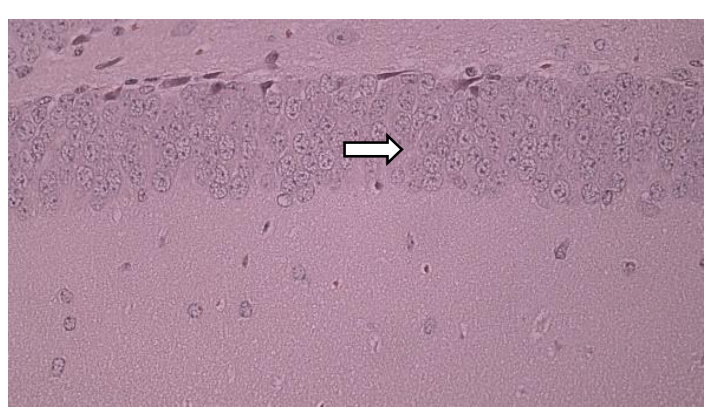

Gambar 3. Piracetam

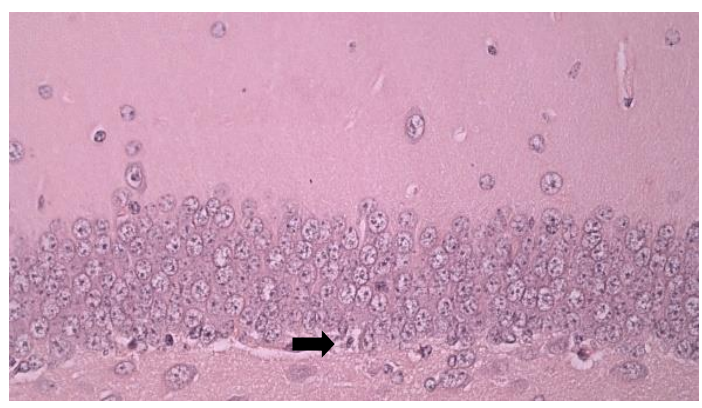

Gambar 5. Etil Asetat

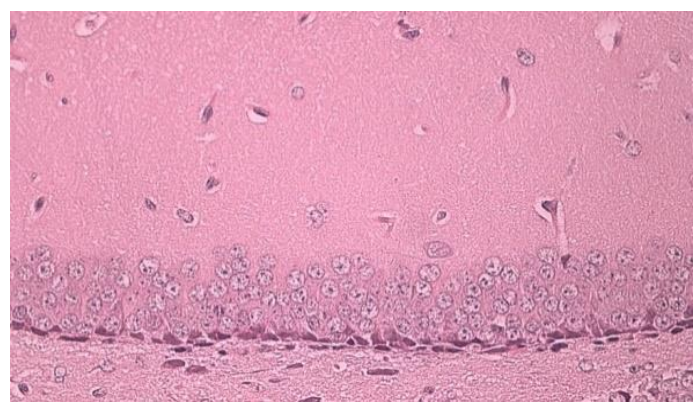

Gambar 2. Diazepam

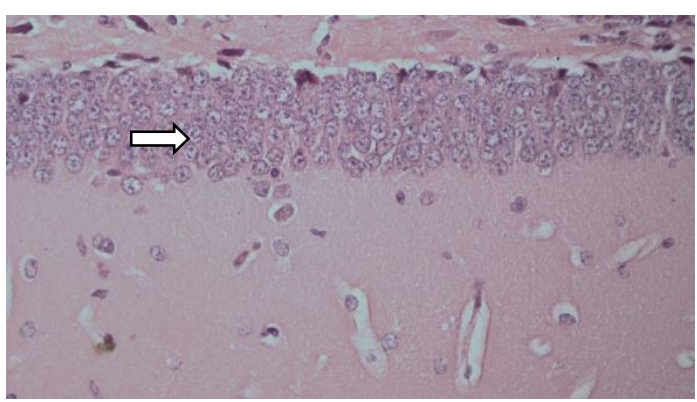

Gambar 4. n-heksan

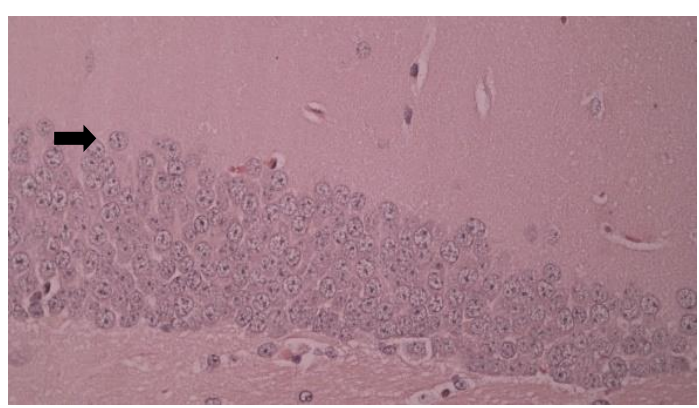

Gambar 6. n-butanol

Ket. Nekrosis sel ditandai dengan bentuk sel tidak beraturan, inti yang memadat dan tidak memiliki inti sel (panah hitam) sedangkan sel normal memiliki inti sel (panah putih)

Berdasarkan hasil pengamatan mikroskopik terhadap gambaran histopatologi otak diatas menunjukkan perbedaan antara kelompok normal, kontrol positif, kontrol negatif dan fraksi. Kelompok normal menunjukan adanya sel neuron normal yang memiliki inti tetapi masih terlihat adanya nekrosis (kematian) sel, hal ini bisa disebabkan karena adanya faktor dari makanan, usia, suhu, dll. Nekrosis sel (kematian sel) otak ditandai dengan bentuk sel tidak beraturan, inti yang memadat dan tidak memiliki inti sel $^{7}$. Menurut penelitian Steven, dkk (2017) kerusakan sel ditandai dengan inti yang piknotik, karioreksis, kariolisis, bentuk sitoplasma tidak teratur, terbentuk krusta, dan terjadi perubahan secara pecahan kromatin yang tersebar didalam sel. merata. Menurut Mujtahid (2016) Kerusakan sel dapat dilihat dengan tidak nampaknya inti sel, hilangnya salah satu lengan dendrit neuron, atau terjadinya pengerutan dari sel.

Ada 3 jenis kerusakan membran sel antara lain piknotik, karioreksis dan kariolisis. Piknotik umumnya perubahan lisis yang terjadi dalam jaringan nekrotik yang melibatkan sitoplasma sel, namun intilah yang paling jelas menunjukkan perubahan-perubahan kematian sel, biasanya inti sel yang mati akan menyebar, mengkerut, memadat, batasnya tidak teratur. Selanjutnya yaitu karioreksis dimana terdapatnya dua inti sel atau setengah, yang dapat hancur dan meninggalkan pecahan- 
Kemudian kariolisis tidak memiliki inti sel atau

Pada penelitian ini hewan uji diinduksi diazepam untuk merusak otak. Dosis diazepam yang diberikan yaitu $0,75 \mathrm{mg} / \mathrm{ml}$, dimana penggunaan dosis diazepam yang tinggi dapat membentuk aktivitas-aktivitas yang menghambat kerja dari hippocampus dan pensinyalan sistem sinaps, dimana proses diazepam menghambat aktivitas hippocampus dengan mempengaruhi hippocampal dependent dan mereduksi konsentrasi kortikosterone ${ }^{13,4}$. Berdasarkan hasil histologi pada kelompok kontrol negatif yang hanya diberikan diazepam terlihat banyaknya nekrosis sel (kematian sel) dibandingkan dengan kelompok lainnya.

Pada kelompok kontrol positif hewan uji diinduksi obat pembanding yaitu piracetam 800 mg. Dimana piracetam diketahui dapat mencegah penurunan fungsi memori yang diakibatkan oleh diazepam. Pencegahan penurunan fungsi memori ini sejalan dengan mekanisme kerja dari pirasetam diantaranya sebagai neuroprotektif dan mencegah kematian neuron oleh radikal bebas ${ }^{14}$. Menurut penelitian Sapto dan Leni (2016) Piracetam (2oxo-1-pyrrolidine-acetamide) adalah analog asam gamma-aminobutyric yang telah digunakan sebagai obat standar untuk meningkatkan fungsi memori pasien demensia.

Pada kelompok perlakuan fraksi n-heksan (T1) terlihat banyak sel yang mengalami nekrosis sel (kematian sel). Nekrosis sel (kematian sel) terjadi karena kurangnya aktifitas fraksi n-heksan sebagai neuroprotektif dan fraksi n-heksan bersifat non polar sehingga sulit untuk berpenetrasi ke otak dan tidak memberikan efek terapi. Kelompok perlakuan fraksi etil asetat (T2) terlihat sedikit sel yang mengalami nekrosis sel (kematian sel) atau mendekati kelompok T3. Fraksi etil asetat bersifat semi polar sehingga memberikan efek terapi yang sedikit ke otak. Dan kelompok perlakuan fraksi n-butanol (T3) terlihat mengalami nekrosis sel (kematian sel) yang mendekati kelompok dengan perlakuan obat pembanding (kontrol positif), hal ini dikarenakan fraksi n-butanol bersifat polar dan juga mengandung senyawa flavonoid. Flavonoid diduga mampu melindungi otak dari jejas yang diinduksi oleh berbagai neurotoksin dan menekan peradangan neuron, dan berpotensi dalam peningkatan fungsi memori (fungsi kognitif dan pembelajaran) dalam berbagai penyakit neurodegeneratif.Hal ini kosong 9 .

sejalan dengan mekanisme kerja flavonoid yang mampu memodulasi protein kinase dan kaskade sinyal lipid kinase, seperti PI3 kinase, protein kinase $\mathrm{C}$, dan mitogen activated -protein (MAP) kinase sehingga terjadi perubahan ekspresi gen dan aktivitas kaspase. Penghambatan terhadap aktivasi kaspase menyebabkan flavonoid mampu menghambat kerusakan sel saraf yang diinduksi oleh stress oksidatif (anti-apoptosis). Dalam mencegah peradangan neuron, flavonoid menekan ekspresi COX-2 dan iNOS, memproduksi NO, pelepasan sitokin, mengaktivasi NADPH oksidase, dan pembentukan ROS ${ }^{6}$.

Menurut Yohana (2016) Flavonoid mengerahkan banyaknya tindakan saraf dalam otak, termasuk potensi untuk melindungi neuron terhadap kerusakan yang disebabkan oleh neurotoksin, kemampuan untuk menekan peradangan saraf, dan potensi untuk meningkatkan memori belajar dan fungsi kognitif. Zin et al (2002) menyatakan bahwa golongan flavonoid merupakan golongan senyawa aktif sebagai antioksidan yang terdapat pada batang, buah dan daun mengkudu. Flavonoid berperan sebagai antioksidan dengan cara menberikan atom hidrogennya atau melalui kemampuannya dalam mengkelat logam, sehingga berada dalam bentuk glukosida (mengandung rantai samping glukosa) atau dalam bentuk bebas yang disebut aglikon.

Selain berfungsi sebagai antioksidan dan antiinflamasi, flavonoid juga dapat meningkatkan fungsi jaringan endotelial dan aliran darah perifer sehingga terjadi peningkatan aliran darah otak (cerebral blood flow/ CBF) dan memicu pembentukan neuron baru di hipokampus. Sel saraf yang baru terbentuk akan memiliki hubungan antar sinaps yang efektif sehingga meningkatkan fungsi memori.

Berdasarkan hasil penelitian sebelumnya tentang performa memori pada hewan model demensia dari ekstrak dan fraksi daun sembung rambat menyatakan bahwa ekstrak memiliki efek yang paling bagus dalam meningkatkan memori spasial mencit yang di induksi aloksan, kemudian fraksi etil asetat, fraksi n-butanol dan fraksi n-heksan ${ }^{3}$. Menurut penelitian Mujtahid (2016) dalam tesisnya tentang pengaruh fraksi herba kemangi terhadap kemapuan memori spasial dan uji histopatologi otak mencit menyatakan bahwa fraksi etil asetat memiliki 
efek yang paling bagus dalam meningkatkan memori spasial mencit ${ }^{10}$.

\section{SIMPULAN}

Berdasarkan hasil pada penelitian ini dapat disimpulkan bahwa Fraksi daun sembung rambat memiliki aktivitas neuroptotektan pada mencit berdasarkan gambaran histopatologi otak mencit.

\section{UCAPAN TERIMA KASIH}

Terima kasih kepada Prof. Drh. Ekowati Handharyani, M. Si, Phd, APVet. Divisi Patologi Fakultas Kedokteran Hewan, Institut Pertanian Bogor (IPB), yang telah banyak membantu proses Histologi pada penelitian ini.

\section{DAFTAR PUSTAKA}

[1] Agustina, W., \& Handayani, D. (2017). Beberapa Fraksi Dari Kulit Batang Jarak ( Ricinus Communis L .). Alotrop Jurnal Pendidikan Dan Ilmu Kimia, 1(2), 117122.

[2] Agustina, W., Setyowati, E., Retno, S., Ariani, D., Rahmawati, C. P., Nasional, S., ... Kimia, P. (2014). Skrining Fitokimia Dan Identifikasi Komponen Utama Ekstrak Metanol Kulit Durian ( Durio Zibethinus Murr .) Varietas Petruk. 271-280.

[3] Andriani, Y., Aliyah, S. H., \& Aminuddin. (2018). Studi In Vivo Aktivitas Ekstrak \& Fraksi Daun Mikania Micrantha. Kunth Terhadap Performa Memori Pada Model Hewan Demensia.

[4] Béracochéa, D. (2011). Interaction Between Diazepam And Hippocampal Corticosterone After Acute Stress: Impact On Memory In Middle-Aged Mice. 5(April), 1-9.

[5] Chetia, J., Upadhyaya, S., \& Bora, D. K. (2014). Research Article Screening Of Phytochemicals, Antioxidant And Antimicrobial Activity of Some Tea Garden Weeds of Tinsukia, Assam. 26(33), 193-196.

[6] Dwi, H., Halim, P., \& Ibrahim, N. (2013). Efek Neuroprotektif Ekstrak Akar
Acalypha Indica Linn $500 \mathrm{Mg} / \mathrm{Kgbb}$ Terhadap Perubahan Inti Sel Saraf Hipokampus Pascahipoksia Serebri.

[7] Kristianingrum, Y. P., Widyarini, S., Sutrisno, B., Patologi, D., Hewan, F. K., \& Mada, U. G. (2016). Gambaran Histopatologi Otak Tikus Akibat Injeksi Trimetyltin Sebagai Model Penyakit Alzheimer. Jurnal Sain Veteriner, 34(1), 84-91.

[8] Lallianchhuanga, M. ., Ali, M. A., Lalchhandama, C., Lalmuanthanga, C., \& Devi, L. I. (2016). World Journal Of Pharmaceutical Research Antioxidant Activity Of Methanolic Extract Of. World Journal of Pharmaceutical Research, 5(4), 879-886.

[9] Mihmidati, L., \& Athiroh, N. (2017). Metanolic Extraction of ( Scurrula Atropurpurea (Bl .) Dans) Effect Which Is Given 90-Days Sub-Chronic On Female Rats ( Rattus Norvegicus ) Toward Necrosis Of Brain E - Jbst Edisi Khusus Oktober 2017 E - Jbst Edisi Khusus Oktober 2017 Material Dan Metod. 3, 16-23.

[10] Mujtahid. (2016). Pengaruh Fraksi Herba Kemangi (Ocimum Sanctum L) Terhadap Kemampuan Memori Spasial Dengan Metode Y Maze Dan Histopatologi Cal Hipokampus Dan Cortex Cerebral Pada Mencit Jantan Galur Balb/C. Universitas Setia Budi.

[11] Perawati, S., Andriani, L., \& Pratama, S. (2019). Aktivitas Koagulan Ekstrak Dan Fraksi Daun Sembung Rambat ( Mikania Micrantha Kunth .). Chempublish Journal, 4(1), 30-37.

[12] Perawati, S., Andriani, L., \& Pratiwi, P. (2018). Aktivitas Antibakteri Ekstrak Etanol Daun Sembung Rambat (Mikania Micrantha Kunth). Chempublish Journal, $3(2), 40-45$.

[13] Pilipenko, V., Narbute, K., Pupure, J., Rumaks, J., Jansone, B., \& Klusa, V. (2019). Neuropharmacology Neuroprotective Action Of Diazepam At Very Low And Moderate Doses In 
Alzheimer , S Disease Model Rats. Neuropharmacology, 144(November 2018), 319-326.

[14] Prasetya, D. Y., \& Yuliani, S. (2014). Aktivitas Ekstrak Rimpang Temulawak ( Curcuma Xanthorrhiza Roxb .) Pada Radial Arm Maze Dan Pasive Avoidance Test Tikus Model Demensia Activity Of Curcuma Xanthorrhiza Roxb . Extract To Radial Arm Maze And Pasive Avoidance Test On Dementia Model Of Rat Di. Pharmaciana, 4(2), 157-164.

[15] Saputro, R. W., Sunarno, \& Mardiati, S. M. (2016). Perbaikan Histologis Pusat Learning And Memory Di Hipokampus Otak Setelah Perlakuan Suplemen Daging Ikan Gabus (Channa Striata) Dalam Pakan: Kajian In Vivo Pada Tikus Wistar Pasca Stres. Jurnal Biologi, 5(3), 1-14.

[16] Yohana, M, A, K. (2016). Pengaruh Fraksi Rimpang Jahe Merah (Zingiber Officinale Roscoe var. rubrum) Terhadap Kemampuan Memori Spasial Dengan Metode Y Maze Dan Histopatologi Cal Hipokampus Dan
Cortex Cerebral Pada Mencit Jantan Galur Balb/C. Universitas Setia Budi. 